\title{
Possible Effects Of Government Action To Curb Global Warming On Stock Market Performance
}

David Nugent, Nugent and Associates, USA

Monsurur Rahman, Indiana University of Pennsylvania, USA

\begin{abstract}
In recent years the stock market has experienced two steep declines. Between March 23, 2000 and October 9, 2002, the $S$ \& $P 500$ index fell from 1,527.35 to 776.76. After rising to an intraday high of 1,576.09 on October 11, 2007, the S \& P 500 index fell to 676.53 on March 9, 2009 (GSPC Historical Prices $S \& P 500$ Stock). Although the stock market has recovered in the years since, the double decline may make investors wonder if the stock market will decline again and what might cause any future decline. Finance theory (Block, 2010) suggests that corporate stock value is affected by investors' expectations of economic growth. The theory of global warming (Brown, 2007) suggests that the production of carbon dioxide and other greenhouse gases causes global temperatures to rise and that the remedy would be the reduction of the production of greenhouse gases. If investors were to perceive that action to reduce greenhouse gases would also reduce economic growth, the result could be declines in stock market returns.
\end{abstract}

This paper presents a theoretical discussion of the possibility that stock market declines may arise if investors were to expect that politicians could take drastic action to curb global warming.

Keywords: Global Warming; Cap and Trade; Stock Market Returns

\section{INTRODUCTION}

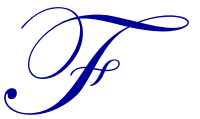

luctuations in stock market returns are due to a number of causes. The internet bubble of the late 1990 's contributed to rising stock prices, the bursting of the internet bubble contributed to stock market declines from 2000 to 2002, and the housing bubble contributed to rising stock prices from 2002 to 2007. Turmoil related to the bursting of the housing bubble, the collapse of financial institutions and widely fluctuating oil prices were blamed for the stock market decline from 2007 to 2009. Future stock market declines may be due to similar factors or those not yet determined. This paper addresses one of those possibilities.

It is posited in this paper that government action that attempts to curb global warming may contribute to stock market declines. This paper addresses the potential role of the consequences of actions that may be taken to address the possibility that emissions of greenhouse gases increases global temperatures and how those actions may cause economic harm. The issue to be addressed is not whether the theory of global warming is correct or whether higher temperatures would affect economic activity. Rather, the issue is whether actions taken by politicians who support the theory will adversely affect economic activity and therefore, corporate stock values.

\section{THEORY OF GLOBAL WARMING}

According to the theory of global warming (Brown, 2007), sunlight heats the surface of the Earth. In a manner comparable to the glass in a greenhouse retaining heat inside the greenhouse, the Earth's atmosphere reduces the radiation of heat into space. Certain gases, called greenhouse gases, are theorized to be largely responsible for the retention of the Sun's heat. It is suggested that increases in greenhouse gases can cause average 
global temperatures to rise. Carbon dioxide, in particular, is theorized to pose a threat of global warming. When hydrocarbons (such as oil, coal, natural gas, and wood) are burned, carbon combines with oxygen to form carbon dioxide. Between the beginning of the industrial revolution (1820's) and 2007, concentrations of carbon dioxide in the atmosphere increased from 280 parts per million to 383 parts per million (Brown, 2007). It is suggested that if concentrations of carbon dioxide continue to increase, average global temperatures will rise. It is further suggested that to slowdown global warming, carbon dioxide emissions should be reduced.

\section{ECONOMIC CONSEQUENCES OF EMISSION REDUCTIONS}

Since a large proportion of economic activity is dependent, either directly or indirectly, on the burning of fuel, it seems likely that a drastic reduction in carbon dioxide emissions would result in a substantial reduction in economic output. If the advice to reduce carbon dioxide emission were taken to the absurd extreme of eliminating all burning, the result could be the reduction of economic activity to levels that existed before the discovery of fire.

Hydroelectric, nuclear, solar, and other alternate sources of electricity provided less than $15 \%$ of the domestically produced electricity in 2012 (US Energy Information Administration, 2013). In the long run, such alternate energy sources may provide for a moderate level of economic activity. In the short run, however, the level of economic activity that could be produced by alternate energy sources would be a small fraction of current output.

To get an idea of how the elimination of carbon dioxide emissions could theoretically affect economic output, consider concepts of marginal productivity described in a typical economics textbook (Samuelson \& Nordhaus, 2004). Imagine a farmer who combines factors of production, such as land, labor, and capital, to produce agricultural output. Suppose the farmer does not own a tractor. Instead, the farmer's employees cultivate the land using horse drawn plows. Now imagine that the farmer buys a tractor. The investment in the tractor and gasoline to run it would result in a tremendous increase in efficiency and output. The number of farmhands required to cultivate the land would be reduced, allowing those farmhands to do other productive work.

Next, consider the reverse of the preceding scenario. Imagine a farmer who currently owns a highly efficient farm using tractors, threshers, and other modern equipment. If fuel that runs the equipment were outlawed, the farmer would be compelled to revert to horse drawn plows, manual harvesting, and other inefficient practices. To achieve prior levels of output, the farmer would need to hire more workers, diverting their efforts from other occupations. The rate of return to the farmer and the value of the farmer's investment would likely fall.

The extreme measure of outlawing all carbon dioxide-producing fuel seems unlikely. Voters would probably not tolerate the drop in standard of living that would be necessary to achieve zero emissions. Perhaps what is more likely would be a compromise that would limit emissions.

Consider the possibility that, as a compromise, attempts were made to limit carbon dioxide emissions through a cap and trade law (Dinan, 2009). Suppose that a cap and trade law were to set a limit (a cap) on total carbon dioxide emissions. Emissions permits would be issued such that total emissions allowed by the permits would equal the cap. Owners of the emissions permits would have the option of either using the permits or selling them in an emissions permit market. The market value of emissions permits would fluctuate with supply and demand and the cost of emissions permits would change the dynamics of business and investment. If the price of emissions permits were to rise to a point that the use of high emission capital assets were unprofitable, companies would abandon the assets. The assets' values would fall, the rate of return on those assets would fall to zero, and the owners of those assets would suffer great losses. If the cost of emissions permits were to not result in the immediate abandonment of assets, the cost might reduce the rate of return such that when the time comes to replace the assets, owners will choose alternates or substitutes.

For industries where fuel consumption is a necessity, emission limits could lead to intractable problems. If a company's growth were dependent on the use of energy, its inability to increase its supply of energy could result in a cessation of growth. While the ability of individual companies to purchase emission permits would enable those companies to grow, fuel intensive industries, as a whole - and perhaps the economy as a whole - would face great impediments to growth. 
If the emissions cap were set lower, the impediments to growth could be greater. For some proponents of emissions control, limiting emissions to current levels would not be enough. Continuation of current levels of emissions means that, theoretically, concentrations of carbon dioxide and global temperatures would continue to rise, albeit at a slower rate than if emissions were to accelerate. Even a substantial reduction in emissions may be inadequate. For example, Levy (2007, p. 163) states, "The reality remains that cutting emissions by half will only double the time for the damaging effects to take place; it will not reverse the trend. What is needed is a global commitment to a sea change that has, as its goal, a zero tolerance toward damaging emissions." This seems to suggest that politicians should literally seek to reduce emissions of carbon dioxide and other greenhouse gases to zero. It also seems to suggest that a cap and trade law may be just the first step in a series of more and more stringent emission restrictions.

\section{POTENTIAL REACTIONS OF INVESTORS AND CHANGES IN STOCK VALUES}

To investors observing the global warming debate, plausible outcomes may seem to range from moderate emission limits that would induce perpetual economic stagnation to tremendous economic decline resulting from extreme reductions in emissions. This range of potential outcomes could give rise to a range of reactions and a range of effects on stock market values.

According to finance theory (Block, 2010), a corporate stock's value can be calculated as the present value of future cash flows, typically in the form of cash dividends. If a company's sales, profits, and dividends were expected to grow, an investor would expect the stock value to grow. Such an investor would expect a rate of return that is the sum of two components: (1) a dividend yield and (2) a capital gain yield. For example, if expected dividend yield were $2 \%$ and expected capital gain yield were $8 \%$, total expected rate of return would be $10 \%$.

To illustrate the calculation of a stock's market value, consider the constant growth valuation model presented by Block (2010). If a company's dividend is expected to grow at a constant rate, the present value of future dividends can be expressed as:

$\mathrm{P}_{\mathrm{o}}=\mathrm{D}_{1} / \mathrm{K}_{\mathrm{e}}-\mathrm{g}$

Symbols are defined as:

$\mathrm{P}_{\mathrm{o}}$ is the market price of the stock today.

$\mathrm{D}_{1}$ is the dividend expected at the end of the coming year.

$\mathrm{K}_{\mathrm{e}}$ is the required total rate of return.

$\mathrm{g}$ is the constant growth rate for dividends.

To illustrate potential changes in stock values, consider first a hypothetical set of dividends, rate of return and growth rate figures that might seem reasonable in the absence of government restrictions on emissions. Suppose that the expected dividend $\left(\mathrm{D}_{1}\right)$ were $\$ 1.00$, the required total rate of return $\left(\mathrm{K}_{\mathrm{e}}\right)$ were $10 \%$ and the expected growth rate $(\mathrm{g})$ were $8 \%$. The market price of the stock $\left(\mathrm{P}_{0}\right)$ would be calculated as:

$\mathrm{P}_{0}=\mathrm{D}_{1} / \mathrm{K}_{\mathrm{e}}-\mathrm{g}$

$=\$ 1.00 /(.10-.08)=\$ 1.00 / .02=\$ 50.00$

Next, consider a scenario that might arise if politicians were to impose laws that would reduce emissions close to zero. Suppose that economic output and dividends were to fall by $80 \%$. In that case, the expected dividend $\left(D_{1}\right)$ would fall from $\$ 1.00$ to $\$ 0.20$. Further, suppose that the growth rate $(\mathrm{g})$ were to fall to zero, while required total rate of return $\left(\mathrm{K}_{\mathrm{e}}\right)$ remains at $10 \%$. The market price of the stock $(\mathrm{Po})$ would be calculated as:

$\mathrm{P}_{0}=\$ 0.20 /(.10-0)=\$ 0.20 / .10=\$ 2.00$

If politicians were to perceive that the preceding magnitude of economic decline would not be politically feasible, some compromising action might be taken instead. Suppose that such a compromise would result in economic output remaining the same, expected dividend $\left(D_{1}\right)$ remaining at $\$ 1.00$, but growth rate $(\mathrm{g})$ reduced to 
zero. Further, suppose that required total rate of return $(\mathrm{Ke})$ remains at $10 \%$. The market price of the stock $\left(\mathrm{P}_{0}\right)$ would be calculated as:

$\mathrm{P}_{0}=\$ 1.00 /(.10-0)=\$ 1.00 / .10=\$ 10.00$

If expectations of zero economic growth were also politically unfeasible, politicians might seek a compromise that would allow a modest rate of economic growth. Suppose that the growth rate in dividends $(\mathrm{g})$ were to fall from $8 \%$ to $4 \%$, while expected dividend $\left(\mathrm{D}_{1}\right)$ were to remain at $\$ 1.00$ and required total rate of return $\left(\mathrm{K}_{\mathrm{e}}\right)$ were to remain at $10 \%$. The market price of the stock $\left(\mathrm{P}_{0}\right)$ would be calculated as:

$\mathrm{P}_{0}=\$ 1.00 /(.10-.04)=\$ 1.00 / .06=\$ 16.67$

These three hypothetical scenarios illustrated above show how government intervention can have catastrophic impact on the stock market values.

\section{CONCLUSIONS}

Although recent fluctuations in stock market returns are probably due mainly to economic turmoil related to the bursting of the housing bubble, the collapse of financial institutions, widely fluctuating oil prices, and other aspects of the recession, it seems plausible that part of the fluctuation may be attributable to investors' perceptions that politicians may impose greenhouse gas emission limits. If emission limits were perceived to have adverse economic consequences, the result could be declines in corporate stock values.

The preceding calculations suggest that if stock value is dependent on expectations of growth in dividends, even a moderate decline in expectations of economic growth could result in a substantial decline in stock value. If actions taken to curb the perceived threat of global warming were to cause economic output to fall, the result could be a tremendous decline in corporate stock values. Stock market decline has the potential to affect large segments of the population. In addition to individuals' investment portfolios, many others are affected by declines in pension fund assets. Retirement plans and the standard of living of retirees may be adversely affected by declines in stock values. Politicians may want to seek a balance between potential economic harm and perceived benefits of reducing emission of greenhouse gases.

\section{AUTHOR INFORMATION}

David Nugent, PhD., CPA., has a Ph.D. in Business Administration from University of Pittsburgh. Most recently he served as a Visiting Assistant Professor of Accounting and Taxation at Robert Morris University. His research has been published in the Journal of Applied Business Research. E-mail: davidanugent@ hotmail.com

Monsurur Rahman, DBA, CPA, CMA, is a Professor of Accounting at Indiana University of Pennsylvania. He received his doctorate from SIU - Carbondale. His research has been published in the International Business \& Economics Research Journal and The National Accounting Journal. E-mail: mrahman@iup.edu (Corresponding author)

\section{REFERENCES}

1. Block, S. B. (2010). Foundations of financial management. New York: McGraw-Hill Irwin.

2. $\quad$ Brown, P. (2007). Global warning: The last chance for change. Pleasantville: The Reader's Digest Association.

3. Dinan, T. M. (2009). Reducing greenhouse gas emissions with a tax or a cap: Implications for efficiency and cost effectiveness. National Tax Journal, LXII(3), 535-553.

4. GSPC Historical Prices S\&P 500 Stock. Retrieved February 3, 2014 from http://finance.yahoo.com

5. Levy, M. (2007). Why the wind blows: A history of weather and global warming. Hinesburg: Upper Access Book Publishers.

6. Samuelson, P. A., \& Nordhaus, W. D. (2004). Economics. New York: McGraw-Hill, Irwin.

7. US Energy Information Administration (2013). Electric Power Monthly, January 2013. 